\title{
An Empirical Analysis of Lead-Lag Relationship among Various Financial Markets
}

\author{
Xiaoli Wang ${ }^{1}$ \\ ${ }^{1}$ Assistant Professor of Finance, School of Management, Marist College, USA \\ Correspondence: Xiaoli Wang, Assistant Professor of Finance, School of Management, Marist College, USA. E-mail: \\ xiaoli.wang@marist.edu \\ Received: November 9, 2014 \\ Accepted: March 2, 2015 \\ Online Published: March 11, 2015 \\ doi:10.5430/afr.v4n2p60 \\ URL: http://dx.doi.org/10.5430/afr.v4n2p60
}

\begin{abstract}
The efficient-market hypothesis (EMH) asserts that financial markets are "informationally efficient", i.e. all relevant information will be fully and immediately reflected in a security's market price. Other researchers however, have disputed the efficient-market hypothesis both empirically and theoretically.

In this paper, we contribute to the discussions of market efficiency by empirically testing the lead-lag relationship among various financial markets. If markets are efficient in processing information, we expect to see a simultaneous movement of various security markets and vice versa. We focus on the index level of three major security markets: the stock market, the derivative market and the fixed income market and conduct two different analyses. First, using daily data, we investigate the general lead-lag relationship of various security markets; second, after introducing an exogenous information shock (FED announcement) to the system, we examine the responses of various security markets. Our overall findings suggest that all three major financial markets (equity, fixed income and derivative) are closely correlated with each other. However, we do see some level of lead-lag relationships among our variables and thus provide certain evidences against the efficient market hypothesis. Our results will offer insights towards a better understanding about how quickly different security markets process and reflect information thus benefit investors who wish to profit from the arbitrage opportunities.
\end{abstract}

Keywords: Efficient market, Lead-lag relationship, Information shock, VAR, Two-step regression

\section{Introduction}

Efficient market hypothesis (Eugene Fama (1970)) argues that security markets are efficient to reflect information about individual company or market as a whole. Given that, security or market information is expected to be reflected in various security markets (stock, bonds, derivatives etc.) simultaneously and there should be a simultaneous movement among various financial markets. Recent empirical researches (Case, Yang and Yildirim (2012) etc) have also demonstrated that the correlation among various asset classes has gone up significantly, thus making diversification even more difficult for investors than ever.

On the other hand, there are researchers disputing the efficient-market hypothesis both empirically and theoretically. For example, behavior finance argues that with the presence of irrational market participants ("technical" analysts and such) trading stocks based on non-valuation related information, there are going to be inefficiently priced stocks. At the same time, there are studies that demonstrate a delay of the information digestion by security markets, and thus also challenge the efficient market hypothesis, such as post-earning-announcement-drift initially proposed by Ball \& Brown (1968) and also documented by other researchers (Bernard Thomas $(1989,1990)$ ).

In this paper, we contribute to the discussions of market efficiency by empirically testing the lead-lag relationship among various financial markets. If markets are efficient in processing information, we expect to see a simultaneous movement of various security markets and vice versa. We focus on the index level of three major security markets: the stock market, the derivative market and the fixed income market and conduct two different analyses. First, using daily data, we investigate the general lead-lag relationship of various security markets; second, after introducing an exogenous information shock (FED announcement) to the system, we examine the responses of various security markets using two step regression analysis.

The rest of the paper is organized as follows: section 2 reviews the relevant literature, section 3 describes the data and methodology, section4 presents the empirical results and conclusions appear in section 5. 


\section{Literature Review}

Efficient market hypothesis, which was developed independently by Paul A. Samuelson (1965) and Eugene F. Fama (1965), has been one of the most influential and debatable ideas in the finance area. Under this theory, it is assumed that asset prices in financial markets should reflect all available information efficiently and spontaneously and thus, prices should always be consistent with 'fundamentals'. The theory also implies that technical analysis provides no useful information and active portfolio management is not necessary.

However, the empirical analysis have provided mixed results: for example some researches demonstrate evidences that stock prices do not adjust instantaneously to profit announcements, such as (Ball and Brown 1968; Chan, Jegadeesh and Lakonishok 1996; Fama 1998). Other stock market anomalies that have been demonstrated in finance researches, such as value effect ((Fama and French 1992), De Bondt and Thaler (1985) etc), momentum effect (Jegadeesh and Titman (1993), etc), size premium ((Banz 1981), (Chan and Chen 1991)), also show that public information helps to predict excess stock returns, and thus are against the efficient market hypothesis.

In addition, behavioral economics and finance analysis have also challenged the efficient market hypothesis by arguing that the markets are not rational, but rather are driven by greed and fear, and thus can lead to a significant market price deviation from the fundamental values. Many behavioral finance empirical literatures also demonstrate various investors' behavior biases that are against efficient market hypothesis, such as over-confidence (Fischo and Slovic (1980); Barber and Odean (2001); Gervais and Odean (2001)), loss aversion (Kahneman and Tversky (1979); Shefrin and Statman (1985); Odean (1998)), overreaction (DeBondt and Thaler (1986)) etc. Lo (2004) proposed a new framework that reconcile market efficiency hypothesis with behavioral alternatives by applying the principles of evolution competition, adaptation, and natural selection to financial interactions.

Other researchers focus on the financial markets lead-lag relationship to investigate the market efficiency issues. If markets are efficient in processing information, we expect all information will be absorbed simultaneously in various markets and there should be no lead-lag movement relationship among various financial markets and vice versa.

Previous lead-lag studies have focused on the relationship between spot markets and future markets and they find that the lagged changes in future price are more likely to lead the short-term adjustments in spot index, but not vice versa. For example, Herbstet al (1987) provides an objective measure of timing relationship between spot stock indices and their future contracts; De Jong and Nijman (1997) investigate the lead-lag relationship between the S\&P index and futures written on it using high frequency data. Brooks, et al (2001) examine the lead-lag relationship between the FTSE 100 index and index futures price employing a number of time series models and Tse (1995) Investigates the lead-lag relationship between the spot index and futures price of the Nikkei Stock Average. Debasish (2009) examines the lead-lag relationships between the National Stock Exchange (NSE) Nifty stock market index (in India) and its related futures and options contracts, and also the interrelation between the derivatives markets. He finds that NSE Nifty derivatives markets tend to lead the underlying stock index.

Recent lead-lag researches have extended the previous analysis to consider the relationship of other security markets or other countries, with a concentration on CDS market. Berndt and Ostrovnay (2007) provide a rigorous analysis of whether and to what extent the credit market acquires information prior to the option market. Their results indicate that investors absorb information revealed in the CDS market into option prices within a few days, i.e. CDS markets lead the option market. Norden and Weber (2009) analyze the empirical relationship between credit default swap, bond markets and stock markets during the period 2000-2002 at the firm level. They use a vector autoregressive model to examine the weekly and daily lead-lag relationship and find that the stock returns lead CDS and bond spread changes. Downing, Underwood, Shane and Xing (2009) examine the lead-lag relationship between high frequency returns on individual stocks and bonds. They find that hourly stock returns lead bond returns for non-convertible junk and BBB-rated bonds, and convertible bonds in all rating classes. Their results indicate that the corporate bond market is less efficient in digesting information than the stock market. Fonsecay and Gottschalkz (2012) also use a VAR model to investigate the lead-lag relationship, but between CDS spreads, realized volatility and stock returns. They find that at the firm level, stock returns lead the other variables while at the index level, the realized volatility and the credit default swap spreads are as important, if not more so, than equity returns.

Conover and Paterson (1999) investigate the lead-lag relationship between the option and stock markets for 17 trading-days prior to substantial earnings surprises, using the Berkeley options data base, changes in put-call parity, and a control option methodology. They find that before the passage of the Insider Trading Sanctions Act (ITSA) in 1984, the option market leads the stock market prior to negative surprises but the stock market leads option market prior to positive surprises; while after the passage of ITSA there is no leading role for either market under positive or negative surprises. Hong, Torous, Walter and Volkanov (2007) study the lead-lag relationship between industry 
portfolios and general stock market movement. They demonstrate that a significant number of industry returns, including retail, commercial real estate, metal, and petroleum, forecast the stock market by up to two months and the eight largest non-US stock markets show remarkably similar patterns. These findings suggest that stock markets react to the information contained in industry returns about their fundamentals with a delay and only digest the information gradually across markets.

Researchers also extend the lead-lag analysis into international markets. Corzo, Gomez-Biscarri, and Lazcano (2012) investigate the relationship between sovereign CDSs and Bonds, and Equity markets for 13 European countries during the period 2008-2010. They document the leading role of Equity markets during the period of 2008-2009, but find large evidence for the leading movement of sovereign CDS markets in 2010. Kolluri, Bharat, Susan Machuga and Mahmoud Wahab, (2014) examine the co-movements relationship of nine Asian equity markets with both the US and Japan. They find that Asian markets returns and volatilities tend to co-move more with US market than with Japan market; and their co-movements with negative US returns far exceed their co-movements with positive US returns. Ilter and Alguner (2013) examines the price discovery and lead-lag relationship between stock index (ISE 100) and stock index futures markets in Turkey over the period 2006-2011. They find that future market reacts earlier than spot market to the information and serves as a useful price discovery tool. Jusoh etc. (2014) analyze the lead-lag relationship between stock index and stock index futures in Malaysia using a new approach based on the Continuous Wavelet Transform (CWT) and the Discrete Wavelet Transform (DWT). Their results indicate that there is variability of the lead-lag relationship across frequency ranges and time scales, and the relationships between stock index and stock index futures are shown to evolve over time with non-homogeneous trends across different time scales.

Our research extends the previous analyses to study the co-movement of three major financial markets: stock market, derivative markets and fixed income market. To our knowledge, we are the first to investigate the lead-lag relationship among three different security markets at the same time. We focus on the market index level instead of individual security for the purpose to study the general movement of the markets and we implement two different methodologies. First, similar to previous literatures, we adopt the Variable Autoregressive Regression (VAR) method to study the general lead-lag movements of the three markets; and second, we introduce an exogenous information shock (FED announcement day) and then use a two-step regression method to explore the responses of various markets. We believe that our methodology of using FED announcement as an information shock to investigate the lead-lag relationship among security market movements is also unique in literature.

A lot of researches have documented the impact of Federal Reserve policy on security markets. For example, Bernanke and Kuttner (2005) analyze the impact of changes in monetary policy on equity prices and they find that, on average, a hypothetical unanticipated 25-basis-point cut in the FED fund rate target is associated with about one percent increase in broad stock indexes. Gürkaynak, Sack \& Swanson (2005) investigate the effects of U.S. monetary policy on bond yields and stock prices using a new intraday dataset going back to 1990 and a high frequency event-study analysis. They find that both monetary policy actions and statements have important but differing effects on asset prices, with statements having a much greater impact on longer-term treasury yields. Goto, \& Valkanov (2000) study the impact of Federal Reserve policy on inflation and find that about 20 to 25 percent of the negative covariance between excess returns and inflation is explained by shocks to monetary policy variables and the finding is robust to changes in the monetary policy rule that have occurred during the 1966-2000 period.

Birru and Figlewski (2010) explore the "informational microstructure" of the stock market around Fed funds target announcements and find evidence against the efficient market digestion of the fed fund information: their results indicate that the market's adjustment to the news continues well beyond the initial information release. Aizenman, Joshua, Binici Mahir and Michael Hutchison (2014) evaluate the response of emerging financial markets to FED tapering news, but for different Fed senior policy makers. They find that emerging market asset prices respond most to statements by FED Chairman Bernake and much less to other FED officials. They also find that fragile emerging markets which received fewer inflows of funds in the first instance during the quantitative years receive less negative impact from the FED tapering news (eg, less exchange rate depreciation, drops in the stock markets, etc). Mishra, Prachi, Kenji Moriyama, Papa N'Diaye, and Lam Nguyen1 (2014) also investigate the emerging market reactions to the 2013-14 FED announcements relating to tapering of asset purchases and their relationship to macroeconomic fundamentals and country economic and financial structures. However, different than the results by Aizenman etc. (2014), their results indicate that countries with stronger macroeconomic fundamentals, deeper financial markets, and a tighter macro prudential policy stance have less impact from FED tapering announcements, i.e. experienced smaller currency depreciations and smaller increases in government bond yields. Nevertheless, these results 
indicate that there are differences in terms of the market reactions to FED announcement by different emerging markets.

In this paper, we also study the impact of FED announcement on different financial markets, but focusing on the U.S. markets only. We investigate the reactions to FED announcement by three security markets in U.S. all together using a two-step regression study.

\section{Data and Methodology}

We obtain daily market index data from Bloomberg. Our data variables include: the S\&P500 index (SPX), which is used to represent the stock market; VIX, CBOEPutwrite index (PUT) (Note 1), and CBOEPut/Call Ratio, which are used as indicators of derivative market; the Investment Grade Credit Default Swap Spread (IGCDS) and High Yield Credit Default Swap Spread (HYCDS), which are used to represent the fixed income market. Most of our data variables span the history from Jan 1st 1990 to July 23, 2012 with IGCDS and HYCDS having a relatively short one: IGCDS is from Oct 29, 2003 while HYCDS is from Feb 11. 2009. We use FED announcement date as a proxy for exogenous information shock. The date information is obtained from www.mypivots.com and covers from the year of 1998 to 2013.

We then perform two analyses. First, we implement VAR method on daily data to investigate the general lead-lag relationship among various security markets. We focus on the movement (first derivative) instead of the index level of variables to inspect the lead-lag relationship. The movement of the variable is calculated as the log change of the variable and later we refer to as log change data variables. Using SPX as an example, the log change of the variable is calculated as $\lg \left(\mathrm{SPX}_{\mathrm{t}} / \mathrm{SPX}_{\mathrm{t}-1}\right)$, while $\mathrm{SPX}_{\mathrm{t}}$ and $\mathrm{SPX}_{\mathrm{t}-1}$ denotes the SPX index level at time $t$ and $\mathrm{t}-1$ respectively.

As a robust check, we also calculate the movement of the variables in two other ways: the percentage change data variable and $\mathrm{SD}$ data variable. In percentage change data set, the change of the variable is calculated as $\left(\mathrm{SPX}_{\mathrm{t}}-\mathrm{SPX}_{\mathrm{t}-1}\right) / \mathrm{SPX} \mathrm{X}_{\mathrm{t}-1}$; while in SD data variable, we standardize the change of the variables by calculating the moving deviation from the variable's past 20-day-mean, i.e. $\left(\mathrm{SPX}_{\mathrm{t}}-\mathrm{mean}\left(\mathrm{SPX} \mathrm{X}_{\mathrm{t}-20-\mathrm{t}}\right)\right) / \mathrm{stdev}\left(\mathrm{SPX}_{\mathrm{t}-20-\mathrm{t}}\right)$ while mean $\left(\mathrm{SPX}_{\mathrm{t}-20-\mathrm{t}}\right)$ and $\operatorname{stdev}\left(\mathrm{SPX}_{\mathrm{t}-20-\mathrm{t}}\right)$ denote the mean and standard of the variables for the past 20 days.

We then use the Vector Autoregressive Method to investigate the co-movement and interaction among the various variables. Following Fonseca and Gottschalk (2012), we assume there are no gaps and the maximum order $\mathrm{p}$ is 3 .

For the second analysis, we introduce exogenous information shocks into the system and then examine the response of different financial markets using a two-step regression analysis.

We use FED announcement as the proxy for our exogenous information shock. We identify the FED announcement days as the date when the FOMC (Federal Open Market Committee) make announcements on interest rates. The information is obtained from my pivots website (http://www.mypivots.com/articles/articles.aspx?artnum=11). We then calculate the movement of the variables (the log change of each variable) for one trading day before the announcement, on the trading day, and three trading days after the announcement respectively. For this study, we focus on three major variables, VIX, SPX and IGCDS with an intention to represent option market, equity market and fixed income market respectively. For example, SPX_Fedminus1, SPX_Fed, SPX_Fedplus1, SPX_Fedplus2, and SPX_Fedplus3 represent the log change of the SPX index one trading day before FED announcement, on the trading day of FED announcement, and three trading days after the FED announcement respectively. Appendix1 provides a detailed list of variable description.

We then use a two -step regression analysis to investigate the lead-lag response of each variable to the information shock.

Step1: On each trading day around the FED announcement, excluding the third trading day after the event, we run regressions of other two variables on this one and obtain residuals. Use SPX_Fedplus2 as an example: we run regression of VIX_Fedplus2 and ICGDS_Fedplus2 on SPX_Fedplus2 separately, and then compute the residuals as RVSplus2res and RISplus2res respectively.

Step2: On each trading day on and after FED announcement, we run regression of each variable on its own lagging variables as well as the residuals we obtain from step 1. Continue from our previous example, on the second step, we run regression of SPX_Fedplus2 on the following variables:

SPX_Fedplus1, SPX_Fed and SPX_Fedminus1 for SPX own lag variables

RVSplus1res, RVSFedres, RVSminus1res which are stand for the residuals obtained from step 1 for the regressions of VIX on SPX. 
RISplus1res, RISFedres, RISminus1res representing the residuals obtained from step1 regressions of IGCDS on SPX.

The purpose of using this two-step regression is to examine the lead-lag cross impact of variables without considering the correlation among concurrent variables. The residuals obtained from regression step 1 can be viewed as the orthogonal impact of VIX and IGCDS on SPX.

As a robust check, we also separate the negative FED announcement day from the positive FED announcement day and repeat the analysis to see whether the information contents make a difference in terms of market responses. The negative FED announcement day is defined as the date when the SPX return on that day is negative while positive FED announcement day is for the positive SPX return on that day.

\section{Empirical Results}

In this section, we present the empirical results. We show the results for the general analysis first and then the results with exogenous information shock.

\subsection{Results with General Analysis}

This session displays the results of our general analysis. Table 1 shows the statistical summary of our variables.

Table 1. Summary Statistics of Variables

This table represents the summary statistics of our variables. Our data include: VIX index (VIX), S\&P500 Index(SPX), CBOE Putwrite index(CBOEPutwrite), IndexPutCallRatio index (IndexPCR.Ratio), Investment Great CDS index( IGCDS) and High Yield CDS index (HYCDS). We show both the statistics at the index level and log of change level. The log change data are calculated as $\lg \left(\mathrm{V}_{\mathrm{t}} / \mathrm{V}_{\mathrm{t}-1}\right)$ where $\mathrm{V}_{\mathrm{t}}$ and $\mathrm{V}_{\mathrm{t}-1}$ denotes the variable at time $\mathrm{t}$ and $\mathrm{t}-1$ respectively.

\begin{tabular}{|c|c|c|c|c|c|c|}
\hline \multicolumn{7}{|c|}{ Index Level Data } \\
\hline & VIX & SPX & CBOEPutwrite & IndexPCR.Ratio & IGCDS & HYCDS \\
\hline Median & 19.06 & 1074.5 & 607.9 & 1.41 & 84.9 & 587.5 \\
\hline Mean & 20.53 & 955.4 & 583.8 & 1.471 & 87.61 & 661.9 \\
\hline SD & 8.19 & 370.87 & 306.33 & 0.38 & 46.38 & 263.52 \\
\hline Min & 9.31 & 295.5 & 127.7 & 0.24 & 29.03 & 381.8 \\
\hline Max & 80.86 & 1565.2 & 1198.5 & 3.89 & 279.31 & 1893.9 \\
\hline \multicolumn{7}{|c|}{ Log of Change Data } \\
\hline & VIX & SPX & CBOEPutwrite & IndexPCR.Ratio & IGCDS & HYCDS \\
\hline Median & -0.0010 & 0.0002 & 0.0002 & 0.0000 & -0.0003 & -0.0003 \\
\hline Mean & -0.0001 & 0.0001 & 0.0002 & 0.0003 & 0.0001 & -0.0004 \\
\hline SD & 0.0261 & 0.0051 & 0.0033 & 0.1218 & 0.0127 & 0.0127 \\
\hline Min & -0.1523 & -0.0411 & -0.0427 & -0.5975 & -0.0786 & -0.0752 \\
\hline Max & 0.2154 & 0.0476 & 0.0476 & 0.6410 & 0.0848 & 0.0730 \\
\hline
\end{tabular}


Table 2 demonstrates the concurrent Pearson correlation among various variables.

Table 2. Pearson Correlation among Various Variables

This table shows the Pearson correlation among our variables. Our data include: VIX index (VIX), S\&P500 Index(SPX), CBOE Putwrite index(CBOEPutwrite), IndexPutCallRatio index (IndexPCR.Ratio), Investment Great CDS index( IGCDS) and High Yield CDS index (HYCDS). We show both the correlation at the index level and log of change level. The log change data are calculated as $\lg \left(\mathrm{V}_{\mathrm{t}} / \mathrm{V}_{\mathrm{t}-1}\right)$ where $\mathrm{V}_{\mathrm{t}}$ and $\mathrm{V}_{\mathrm{t}-1}$ denotes the variable at time $t$ and t-1 respectively.

\begin{tabular}{lllllll}
\hline Index Level Data & & & & & & \\
\hline & Vix & SPX & CBOEPutwrite & IndexPCR.Ratio & IGCDS & HYCDS \\
VIX & 1.000 & 0.140 & 0.183 & -0.187 & 0.886 & 0.798 \\
SPX & & 1.000 & 0.865 & 0.167 & -0.564 & -0.789 \\
CBOEPutwrite & & & 1.000 & -0.006 & 0.132 & -0.737 \\
IndexPCR.Ratio & & & & 1.000 & -0.356 & -0.158 \\
IGCDS & & & & 1.000 & 0.951 \\
HYCDS & & & & & & 1.000 \\
SPXR & & & & & & \\
\hline Log Change Data & & & & & & \\
\hline & Vix & SPX & CBOEPutwrite & IndexPCR.Ratio & IGCDS & HYCDS \\
VIX & 1.000 & -0.711 & -0.671 & 0.174 & 0.525 & 0.658 \\
SPX & & 1.000 & 0.882 & -0.154 & -0.572 & -0.697 \\
CBOEPutwrite & & & 1.000 & -0.136 & -0.524 & -0.640 \\
IndexPCR.Ratio & & & & 1.000 & 0.074 & 0.135 \\
IGCDS & & & & & 1.000 & 0.800 \\
HYCDS & & & & & & 1.000 \\
\hline
\end{tabular}

There are some interesting observations we note from Table 2. For example, we see that SPX has a very high correlation with CBOEPutwrite. This probably make sense, as when SPX index level is high or goes up, put options becomes cheaper so that a short strategy of put option will have better performance. We also note that SPX have high level of negative correlation with both investment grade and high yield CDS spread. This implies that when SPX performs well, the market is relatively at ease so that CDS spreads are smaller and vice versa. VIX however, have significant positive correlations with both IGCDS and HYCDS. We believe this is due to the fact that all of the three variables are some sort of fear gears of the market, and thus move in the same direction.

We then examine the unit root problem of our data variables using the augmented dicky-filler test. As table 3 indicates, we don't see a unit root problem with our data variables. 
Table 3. Augmented Dickey-Fuller (ADF) Test Result

This table displays the Augmented Dickey-Fuller (ADF) test results among our variables. Our data include: VIX index (VIX), S\&P500 Index(SPX), CBOE Putwrite index(CBOEPutwrite), IndexPutCallRatio index (IndexPCR.Ratio), Investment Great CDS index( IGCDS) and High Yield CDS index (HYCDS). The log change data are calculated as $\lg \left(\mathrm{V}_{\mathrm{t}} / \mathrm{V}_{\mathrm{t}-1}\right)$ and the percentage change variable is calculated as $\left(\mathrm{V}_{\mathrm{t}}-\mathrm{V}_{\mathrm{t}-1}\right) / \mathrm{V}_{\mathrm{t}-1}$ where $\mathrm{V}_{\mathrm{t}}$ and $\mathrm{V}_{\mathrm{t}-1}$ denotes the variable at time $t$ and $t-1$ respectively. In SD data variable, we standardize the change of the variables by calculating the moving deviation from the variable's past 20 -day-mean, i.e. $\left(\mathrm{V}_{\mathrm{t}}-\mathrm{mean}\left(\mathrm{V}_{\mathrm{t}-20-\mathrm{t}}\right)\right) / \operatorname{stdev}\left(\mathrm{V}_{\mathrm{t}-20-\mathrm{t}}\right)$ while mean $\left(\mathrm{V}_{\mathrm{t}-20-\mathrm{t}}\right)$ and $\operatorname{stdev}\left(\mathrm{V}_{\mathrm{t}-20-\mathrm{t}}\right)$ denote the mean and standard of the variables for the past 20 days respectively.

\begin{tabular}{|c|c|c|c|c|c|}
\hline \multicolumn{3}{|l|}{ Index Level Data } & \multicolumn{3}{|l|}{ Log Change Data } \\
\hline & T Test & P Value & & T Test & P Value \\
\hline VIX & -29.997 & $<2 \mathrm{e}-16 * * *$ & VIX & -38.748 & $<2 \mathrm{e}-16 * * *$ \\
\hline SPX & -29.606 & $<2 \mathrm{e}-16 * * *$ & SPX & -38.829 & $<2 \mathrm{e}-16 * * *$ \\
\hline CBOEPutwrite & -28.863 & $<2 \mathrm{e}-16^{* * *}$ & CBOEPutwrite & -38.513 & $<2 \mathrm{e}-16 * * *$ \\
\hline IndexPCR.Ratio & -5.682 & $1.40 \mathrm{e}-08 * * *$ & IndexPCR.Ratio & -10.243 & $<2 \mathrm{e}-16 * * *$ \\
\hline IGCDS & -7.426 & $1.28 \mathrm{e}-13 * * *$ & IGCDS & -9.654 & $<2 \mathrm{e}-16 * * *$ \\
\hline HYCDS & -2.527 & $0.0115 *$ & HYCDS & -2.313 & $0.0207 *$ \\
\hline SPXR & -35.27 & $<2 \mathrm{e}-16 * * *$ & & & \\
\hline \multirow[t]{2}{*}{ SD Data } & & & \multicolumn{3}{|c|}{ Percentage Change Data } \\
\hline & T Test & P Value & & T Test & P Value \\
\hline VIX & -26.15 & $<2 \mathrm{e}-16 * * *$ & VIX & -38.748 & $<2 \mathrm{e}-16 * * *$ \\
\hline SPX & -25.801 & $<2 \mathrm{e}-16 * * *$ & SPX & -38.829 & $<2 \mathrm{e}-16 * * *$ \\
\hline CBOEPutwrite & -25.835 & $<2 \mathrm{e}-16 * * *$ & CBOEPutwrite & -38.513 & $<2 \mathrm{e}-16 * * *$ \\
\hline IndexPCR.Ratio & -6.109 & $1.07 \mathrm{e}-09 * * *$ & IndexPCR.Ratio & -10.243 & $<2 \mathrm{e}-16 * * *$ \\
\hline IGCDS & -7.793 & $7.72 \mathrm{e}-15 * * *$ & IGCDS & -9.654 & $<2 \mathrm{e}-16 * * *$ \\
\hline HYCDS & -2.183 & $0.0291 *$ & HYCDS & -2.313 & $0.0207 *$ \\
\hline
\end{tabular}

$* * *, * *, *,$. , indicate significance at 0.001, and $0.01,0.5$ and 0.1 respectively.

A VAR estimation model is then performed to probe the lead-lag relationship among various variables. Following previous literature, we use a maximum of lag level 3 in our analysis. As a robust check, we also investigate the lag level of 5 and results are not significantly different.

We study the lead-lag relationship among five variables: SPX, VIX, IndexPCR.Ratio and IGCDs and HYCDs the results are shown in Table 4. 
Table 4. VAR Test of VIX, SPX and IndexPutWrite Ratio, IGCS or HYGS Result

This table illustrates VAR test results among our variables. Our data include: VIX index (VIX), S\&P500 Index (SPX), IndexPutCallRatio index (IndexPCR.Ratio), Investment Great CDS index (IGCDS) and High Yield CDS index (HYCDS). The log change data are calculated as $\lg \left(\mathrm{V}_{\mathrm{t}} / \mathrm{V}_{\mathrm{t}-1}\right)$ and the percentage change variable is calculated as $\left(\mathrm{V}_{\mathrm{t}}-\mathrm{V}_{\mathrm{t}-1}\right) / \mathrm{V}_{\mathrm{t}-1}$ where $\mathrm{V}_{\mathrm{t}}$ and $\mathrm{V}_{\mathrm{t}-1}$ denotes the variable at time $\mathrm{t}$ and $\mathrm{t}-1$ respectively.

\begin{tabular}{|c|c|c|c|c|c|c|c|c|c|c|}
\hline \multicolumn{11}{|l|}{ Log Change Data } \\
\hline & \multicolumn{2}{|l|}{ VIX } & \multicolumn{2}{|l|}{ SPX } & \multicolumn{2}{|c|}{ IndexPCR.Ratio } & \multicolumn{2}{|l|}{ IGCDS } & \multicolumn{2}{|l|}{ HYCDS } \\
\hline & Coefficient & $\mathrm{t}$ value & Coefficient & $\mathrm{t}$ value & Coefficient & t value & Coefficient & t value & Coefficient & $\mathrm{t}$ value \\
\hline Vix.11 & -0.141 & $-2.405^{*}$ & 0.014 & 1.280 & -0.055 & -0.343 & -0.062 & $-2.517 *$ & -0.030 & -1.176 \\
\hline SPXR.11 & 0.327 & 0.991 & -0.122 & -1.912 . & -0.755 & -0.836 & -0.138 & -0.991 & -0.127 & -0.890 \\
\hline IndexPCR.Ratio.11 & 0.028 & $2.152^{*}$ & -0.004 & $\begin{array}{l}-1.788 . \\
-\end{array}$ & -0.604 & - & 0.011 & $2.124^{*}$ & 0.006 & 1.162 \\
\hline IGCDS.11 & 0.442 & $3.044 * *$ & -0.086 & $3.052 * *$ & 0.007 & 0.017 & 0.119 & 1.948. & 0.161 & $2.572 *$ \\
\hline HYCDS.11 & -0.146 & -1.018 & 0.029 & 1.049 & 0.218 & 0.555 & -0.022 & -0.368 & -0.074 & -1.200 \\
\hline Vix.12 & -0.015 & -0.262 & 0.003 & 0.228 & 0.364 & $2.266^{*}$ & -0.025 & -1.012 & 0.003 & 0.112 \\
\hline SPXR.12 & 0.188 & 0.567 & 0.065 & 1.008 & 1.915 & $2.105^{*}$ & -0.375 & $2.679^{* *}$ & -0.226 & -1.574 \\
\hline IndexPCR.Ratio.12 & 0.006 & 0.435 & -0.001 & -0.246 & -0.343 & $-8.733 * * *$ & 0.003 & 0.517 & 0.001 & 0.231 \\
\hline IGCDS.12 & -0.021 & -0.144 & 0.021 & 0.768 & -0.483 & -1.218 & -0.015 & -0.245 & -0.043 & -0.682 \\
\hline HYCDS.12 & 0.129 & 0.904 & -0.028 & -1.024 & 0.352 & 0.899 & -0.057 & -0.953 & 0.026 & 0.418 \\
\hline Vix.13 & -0.087 & -1.492 & 0.012 & 1.087 & 0.134 & 0.840 & -0.004 & -0.161 & 0.022 & 0.875 \\
\hline SPXR.13 & 0.251 & 0.756 & -0.007 & -0.106 & 0.969 & 1.066 & -0.156 & -1.111 & 0.055 & 0.386 \\
\hline IndexPCR.Ratio.13 & 0.001 & 0.086 & 0.000 & -0.172 & -0.139 & $-3.989 * * *$ & 0.001 & 0.100 & -0.001 & -0.137 \\
\hline IGCDS.13 & -0.052 & -0.361 & 0.034 & 1.230 & 0.089 & 0.226 & -0.114 & -1.872 & -0.036 & -0.576 \\
\hline HYCDS.13 & 0.074 & 0.525 & -0.032 & -1.160 & -0.210 & -0.542 & 0.015 & 0.257 & -0.008 & -0.133 \\
\hline const & -0.002 & -0.869 & 0.001 & 1.290 & 0.003 & 0.547 & -0.001 & -0.914 & -0.001 & -1.475 \\
\hline trend & 0.000 & 0.140 & 0.000 & -0.646 & 0.000 & -0.563 & 0.000 & 0.724 & 0.000 & 1.239 \\
\hline
\end{tabular}

From the VAR analysis, we have the following observations:

(1) There are different levels of auto-correlations among our variables. For example, from Table 4, we see that with log change variable, VIX lag1 has a negative coefficient of -0.141 at $5 \%$ significance level for regression of VIX; variable SPX lag1 has a coefficient of -0.122 at $10 \%$ significance level on SPX regression and variable CBOE index Put/call ratio lag1 has a coefficient of -0.604 , significant at $0.1 \%$ level on regression of CBOE index Put/call ratio. These negative lag1 coefficients imply that there is a somewhat one day mean reversion in financial markets, although the relationship is relatively weaker for SPX (only marginally significant at 10\%). On the other hand, the lag1 coefficient is positive (0.119) at $10 \%$ level for IGCDs and not significant for variable HYCDS, suggesting a weak auto-correlation for these variables.

(2) It seems that VIX and SPX are more likely to co-move with each other as we see no significance in terms of the explaining power of each other. For example, in our VIX equation, none of the SPX (SPX lag) variables have significant coefficients and vice versa for SPX equation.

(3) CBOE index PCR.ratio seems to have a circular lead-lag relationship with SPX and VIX, with the changes of SPX or VIX leading the change of the CBOE index PCR.ratio first. As we can see from the table, both SPX and VIX are significant in explain the movement of COBE index PCR.ratio with lag2 variable, while at the same time, CBOE index PCR.ratiois significant in both SPX and VIX equations with lag1 variable.

(4) The relation between IGCDS and SPX is similar to the relationship between PCR.ratio and SPX. It seems that they have a circular lead-lag movement with SPX leading IGCDS. The relationship between IGCDS and VIX is more simultaneous: with a more symmetric cross explaining power of each other. For example: IGCDS lag1 is significant in VIX equation and at the same time VIX lag1 is significant in IGCDS regression.

(5) In HYCDs equation, we don't see any significant variables except IGCDs. This might implies that the change of the HYCDs is only affected by the fixed income factor. And HYCDS have no explaining power for other variables. 
As a robust check, we re-run the general analysis with two percentage change variables and SD change variables and the results are similar.

\subsection{Results with Exogenous Information Shock}

In this session, we present the results with exogenous information shock: FED Announcement. Our FED Day information is obtained from "mypivots" website. We focus on three variables: SPX, VIX and IGCDS, which represents equity market, option market and fixed income market respectively. We calculate the movement of each variable for 5 trading days around FED Announcement and they are: one trading day before FED Announcement, trading day on FED Announcement and three trading days after FED Announcement. We use Fedminus1, Fed, Fedplus1, Fedplus2 and Fedplus3 to represent them respectively.

First, we run Pearson correlation among various variables and the result is presented in Table 5.

Table 5. Pearson Correlation of Variable around FED Announcement Day

Table 5 shows the Pearson correlation among various variables around FED Announcement Day. We focus on three security variables: SPX, VIX and IGCDS, and calculate the log change of each variable on 5 days around FED Announcement: one trading day before the announcement, on the FED announcement day, and three trading days after the announcement. We call them Fedminus1, Fed, Fedplus1, Fedplus2 and Fedplus3 respectively.

\begin{tabular}{|c|c|c|c|c|c|c|c|c|c|c|c|c|c|c|c|}
\hline & $\begin{array}{l}\text { SPX } \\
\text { Fedmi } \\
\text { nus1 }\end{array}$ & $\begin{array}{l}\text { SPX } \\
\text { Fed }\end{array}$ & $\begin{array}{l}\text { SPX } \\
\text { Fedpl } \\
\text { us1 }\end{array}$ & $\begin{array}{l}\text { SPX_ } \\
\text { Fedpl } \\
\text { us2 }\end{array}$ & $\begin{array}{l}\text { SPX_ } \\
\text { Fedpl } \\
\text { us3 }\end{array}$ & $\begin{array}{l}\text { VIX_F } \\
\text { edmin } \\
\text { us1 }\end{array}$ & $\begin{array}{l}\text { VIX } \\
\text { Fed }\end{array}$ & $\begin{array}{l}\text { VIX_ } \\
\text { Fedpl } \\
\text { us1 }\end{array}$ & $\begin{array}{l}\text { VIX_ } \\
\text { Fedpl } \\
\text { us2 }\end{array}$ & $\begin{array}{l}\text { VIX_ } \\
\text { Fedpl } \\
\text { us3 }\end{array}$ & $\begin{array}{l}\text { IGCD } \\
\text { S_Fed } \\
\text { minus } \\
1\end{array}$ & $\begin{array}{l}\text { IGCDS } \\
\text { Fed }\end{array}$ & $\begin{array}{l}\text { IGCD } \\
\text { S_Fed } \\
\text { plus1 }\end{array}$ & $\begin{array}{l}\text { IGCD } \\
\text { S_Fed } \\
\text { plus2 }\end{array}$ & $\begin{array}{l}\text { IGCD } \\
\text { S_Fe } \\
\text { d_Plu } \\
\text { s3 }\end{array}$ \\
\hline $\begin{array}{l}\text { SPX_Fedmin } \\
\text { us1 }\end{array}$ & 1.000 & -0.221 & 0.297 & -0.130 & -0.116 & -0.722 & 0.210 & -0.214 & 0.047 & 0.021 & -0.417 & -0.066 & -0.236 & -0.077 & 0.180 \\
\hline SPX_Fed & & 1.000 & -0.136 & 0.006 & 0.041 & 0.198 & -0.797 & 0.168 & 0.020 & 0.074 & 0.137 & -0.740 & -0.214 & -0.075 & $\begin{array}{l}- \\
0.274\end{array}$ \\
\hline $\begin{array}{l}\text { SPX_Fedplus } \\
1\end{array}$ & & & 1.000 & -0.091 & -0.453 & -0.140 & 0.069 & -0.808 & 0.056 & 0.290 & -0.110 & -0.021 & -0.547 & -0.039 & 0.319 \\
\hline $\begin{array}{l}\text { SPX_Fedplus } \\
2\end{array}$ & & & & 1.000 & -0.057 & 0.164 & -0.162 & 0.214 & $\begin{array}{l}- \\
0.690\end{array}$ & 0.019 & 0.175 & -0.027 & 0.271 & -0.318 & $\overline{-}-$ \\
\hline $\begin{array}{l}\text { SPX_Fedplus } \\
3\end{array}$ & & & & & 1.000 & 0.002 & -0.012 & 0.320 & 0.157 & $\begin{array}{l}- \\
0.698\end{array}$ & -0.011 & -0.021 & 0.177 & -0.010 & $\begin{array}{l}- \\
0.424\end{array}$ \\
\hline $\begin{array}{l}\text { VIX_Fedmin } \\
\text { us1 }\end{array}$ & & & & & & 1.000 & -0.255 & 0.125 & $\begin{array}{l}- \\
0.088\end{array}$ & $\begin{array}{l}- \\
0.032\end{array}$ & 0.577 & -0.046 & 0.127 & -0.060 & $-\overline{0.191}$ \\
\hline VIX_Fed & & & & & & & 1.000 & -0.174 & 0.016 & $\begin{array}{l}- \\
0.033\end{array}$ & -0.208 & 0.656 & 0.168 & -0.008 & 0.169 \\
\hline VIX_Fedplus & & & & & & & & & - & - & & & & & - \\
\hline 1 & & & & & & & & 1.000 & 0.188 & 0.183 & 0.084 & -0.023 & 0.539 & -0.039 & 0.297 \\
\hline $\begin{array}{l}\text { VIX_Fedplus } \\
2\end{array}$ & & & & & & & & & 1.000 & $\begin{array}{l}- \\
0.112\end{array}$ & 0.001 & -0.008 & -0.200 & 0.384 & 0.164 \\
\hline $\begin{array}{l}\text { VIX_Fedplus } \\
3\end{array}$ & & & & & & & & & & 1.000 & -0.170 & 0.083 & -0.091 & -0.047 & 0.374 \\
\hline $\begin{array}{l}\text { IGCDS_Fedm } \\
\text { inus1 }\end{array}$ & & & & & & & & & & & 1.000 & 0.028 & 0.160 & -0.137 & $\begin{array}{l}- \\
0.031\end{array}$ \\
\hline IGCDS_Fed & & & & & & & & & & & & 1.000 & 0.351 & 0.004 & 0.243 \\
\hline $\begin{array}{l}\text { IGCDS_Fedpl } \\
\text { us1 }\end{array}$ & & & & & & & & & & & & & 1.000 & 0.022 & $\begin{array}{l}- \\
0.105\end{array}$ \\
\hline $\begin{array}{l}\text { IGCDS_Fedpl } \\
\text { us } 2\end{array}$ & & & & & & & & & & & & & & 1.000 & 0.334 \\
\hline $\begin{array}{l}\text { IGCDS_Fed_ } \\
\text { Plus3 }\end{array}$ & & & & & & & & & & & & & & & 1.000 \\
\hline
\end{tabular}

As we can see from table 5, there are strong correlations among variables at concurrent level on various trading days. For example, the correlation between SPX and VIX is -0.722 on the trading day before FED announcement, -0.797 on the FED day, -0.808 on the first trading day after FED announcement, -0.69 on the second trading day after FED announcement and -0.698 on the third trading day after FED Announcement, much more significant than the 
cross-day correlations. This implies that the majority of the response to the exogenous information shock might come from the three financial markets simultaneously.

We then perform a two-step regression analysis to investigate the orthogonal lead-lag response of various financial markets after excluding the cross impact of concurrent variables. Due to the short history of IGCDS variable, we run two sets of regression analysis, one exclude IGCDS (only focus on the cross impact of VIX and SPX) and one include IGCDS. The results are shown in Table 6.

Table 6. Two-Step Regression Results: Full Sample

Table 6 displays the full sample results of the two-step regressions. Step1: On each trading day around the FED announcement, excluding the third trading day after the event, we run regressions of other two variables on each variable and obtain residuals. Step2: On each trading day on and after FED announcement, we run regression of each variable on its own lagging variables as well as the residuals we obtained from step 1. The purpose of using these two-step regressions is to examine the orthogonal lead-lag impact of variables without considering the correlation between concurrent variables. Due to short history of IGCDS variable, we run two sets of regression analysis, one exclude IGCDS (only focus on the cross impact of VIX and SPX) and one include IGCDS, and results are shown on session A to E respectively.

\begin{tabular}{|c|c|c|c|c|c|c|c|c|}
\hline \multicolumn{9}{|c|}{ A: Two-step Regression of VIX on SPX Residual Impact only } \\
\hline & \multicolumn{2}{|c|}{ VIX_Fedplus3 } & \multicolumn{2}{|c|}{ VIX_Fedplus2 } & \multicolumn{2}{|c|}{ VIX_Fedplus1 } & \multicolumn{2}{|l|}{ VIX_Fed } \\
\hline & Estimate & t value & Estimate & t value & Estimate & t value & Estimate & t value \\
\hline (Intercept) & -0.001 & -0.256 & -0.001 & -0.587 & -0.002 & -0.714 & -0.011 & $-3.966 * * *$ \\
\hline VIX_Fedplus2 & -0.133 & -1.321 & & & & & & \\
\hline VIX_Fedplus1 & -0.195 & $-2.458 *$ & -0.148 & $-2.03 *$ & & & & \\
\hline VIX_Fed & -0.041 & -0.492 & -0.048 & -0.629 & -0.149 & -1.560 & & \\
\hline VIX_Fedminus1 & -0.001 & -0.006 & -0.069 & -0.951 & 0.087 & 0.943 & -0.246 & $-2.856 * *$ \\
\hline RSVplus2res & -0.369 & -0.537 & & & & & & \\
\hline RSVplus1res & 1.579 & $2.735 * *$ & -0.940 & -1.761. & & & & \\
\hline RSVFedres & 0.797 & 1.236 & 0.219 & 0.375 & 0.209 & 0.281 & & \\
\hline RSVminus1res & -0.475 & -0.994 & -0.051 & -0.114 & -1.030 & -1.875 . & 0.220 & 0.419 \\
\hline
\end{tabular}

B: Two-step Regression of SPX on VIX Residual Impact only

\begin{tabular}{|c|c|c|c|c|c|c|c|c|}
\hline & \multicolumn{2}{|c|}{ SPX_Fedplus3 } & \multicolumn{2}{|c|}{ SPX_Fedplus2 } & \multicolumn{2}{|c|}{ SPX_Fedplus1 } & \multicolumn{2}{|l|}{ SPX_Fed } \\
\hline & Estimate & t value & Estimate & t value & Estimate & t value & Estimate & t value \\
\hline (Intercept) & 0.000 & 0.735 & 0.000 & -0.351 & -0.001 & -0.833 & 0.002 & $3.049^{* *}$ \\
\hline SPX_Fedplus2 & -0.121 & -0.954 & & & & & & \\
\hline SPX_Fedplus1 & -0.451 & $-5.246 * * *$ & -0.058 & -0.910 & & & & \\
\hline SPX_Fed & -0.018 & -0.180 & -0.043 & -0.599 & -0.092 & -0.875 & & \\
\hline SPX_Fedminus 1 & 0.016 & 0.192 & -0.076 & -1.210 & 0.278 & $3.129 * *$ & -0.187 & $-2.46^{*}$ \\
\hline RVSplus2res & 0.063 & 1.801 . & & & & & & \\
\hline RVSplus1res & -0.015 & -0.434 & 0.055 & $2.231^{*}$ & & & & \\
\hline RVSFedres & -0.004 & -0.110 & -0.057 & $-2.289 *$ & -0.025 & -0.703 & & \\
\hline RVSminus1res & -0.019 & -0.682 & 0.014 & 0.696 & 0.034 & 1.125 & 0.016 & 0.609 \\
\hline \multicolumn{9}{|c|}{ C: Two-step Regression of VIX on Residual Impact of SPX and IGCDS } \\
\hline & \multicolumn{2}{|c|}{ VIX_Fedplus3 } & \multicolumn{2}{|c|}{ VIX_Fedplus2 } & \multicolumn{2}{|c|}{ VIX_Fedplus1 } & \multicolumn{2}{|l|}{ VIX_Fed } \\
\hline & Estimate & t value & Estimate & t value & Estimate & t value & Estimate & t value \\
\hline (Intercept) & -0.002 & -0.692 & 0.002 & 0.523 & 0.003 & 0.653 & -0.012 & $-2.994 * *$ \\
\hline VIX_Fedplus2 & -0.119 & -1.073 & & & & & & \\
\hline VIX_Fedplus1 & -0.154 & -1.670 & -0.173 & -1.694. & & & & \\
\hline
\end{tabular}




\begin{tabular}{|c|c|c|c|c|c|c|c|c|}
\hline VIX_Fed & -0.036 & -0.371 & -0.020 & -0.182 & -0.121 & -0.941 & & \\
\hline VIX_Fedminus1 & -0.001 & -0.014 & -0.095 & -0.938 & 0.131 & 1.108 & -0.283 & $-2.709 * *$ \\
\hline RSVplus2res & -0.792 & -0.830 & & & & & & \\
\hline RSVplus1res & 2.541 & $3.148 * *$ & -2.065 & $-2.338^{*}$ & & & & \\
\hline RSVFedres & 0.242 & 0.223 & -1.417 & -1.305 & -0.205 & -0.153 & & \\
\hline RSVminus1res & -0.239 & -0.394 & 0.289 & 0.431 & -1.568 & $-2.125^{*}$ & 0.102 & 0.151 \\
\hline RIVplus2res & 0.023 & 0.108 & & & & & & \\
\hline RIVplus1res & 0.091 & 0.425 & -0.270 & -1.140 & & & & \\
\hline RIVFedres & 0.415 & 1.090 & -0.013 & -0.030 & 0.086 & 0.172 & & \\
\hline RIVminus1res & -0.453 & -1.467 & 0.249 & 0.721 & -0.098 & -0.232 & -0.122 & -0.301 \\
\hline \multicolumn{9}{|c|}{ D: Two-step Regression of SPX on Residual Impact of VIX and IGCDS } \\
\hline & \multicolumn{2}{|c|}{ SPX_Fedplus3 } & \multicolumn{2}{|c|}{ SPX_Fedplus2 } & \multicolumn{2}{|c|}{ SPX_Fedplus2 } & \multicolumn{2}{|l|}{ SPX_Fed } \\
\hline & Estimate & t value & Estimate & t value & Estimate & t value & Estimate & $\mathrm{t}$ value \\
\hline (Intercept) & 0.001 & 0.874 & 0.000 & -0.089 & -0.001 & -1.543 & 0.002 & $2.656^{* *}$ \\
\hline SPX_Fedplus2 & -0.137 & -0.808 & & & & & & \\
\hline SPX_Fedplus1 & -0.552 & $-4.551 * * *$ & -0.045 & -0.483 & & & & \\
\hline SPX_Fed & 0.015 & 0.104 & -0.046 & -0.424 & -0.049 & -0.353 & & \\
\hline SPX_Fedminus1 & -0.068 & -0.539 & -0.176 & -1.911 & 0.451 & $4.16^{* * *}$ & -0.179 & $-2.093^{*}$ \\
\hline RVSplus2res & 0.080 & 1.659 & & & & & & \\
\hline RVSplus1res & -0.087 & -1.923. & 0.074 & $2.255^{*}$ & & & & \\
\hline RVSFedres & 0.037 & 0.817 & -0.020 & -0.600 & -0.013 & -0.290 & & \\
\hline RVSminus1res & -0.036 & -1.038 & 0.029 & 1.085 & 0.031 & 0.858 & 0.030 & 0.937 \\
\hline RISplus2res & -0.097 & -1.652 & & & & & & \\
\hline RISplus1res & -0.003 & -0.059 & 0.064 & 1.476 & & & & \\
\hline RISFedres & -0.098 & -0.945 & -0.098 & -1.277 & 0.006 & 0.055 & & \\
\hline RISminus1res & -0.035 & -0.417 & -0.003 & -0.040 & 0.042 & 0.487 & -0.010 & -0.135 \\
\hline
\end{tabular}

E: Two-step Regression of IGCDS on the Residual Impact of SPX and VIX

\begin{tabular}{lllllllll}
\hline & \multicolumn{2}{l}{ IGCDS_Fedplus3 } & \multicolumn{2}{l}{ IGCDS_Fedplus2 } & \multicolumn{2}{l}{ IGCDS_Fedplus1 } & \multicolumn{2}{l}{ IGCDS_Fed } \\
\hline & Estimate & $\mathrm{t}$ value & Estimate & $\mathrm{t}$ value & Estimate & $\mathrm{t}$ value & Estimate & $\mathrm{t}$ value \\
\hline (Intercept) & -0.002 & -0.910 & 0.000 & 0.004 & 0.000 & 0.080 & -0.004 & $-2.286^{*}$ \\
IGCDS_Fedplus2 & 0.337 & $2.998^{* *}$ & & & & & & \\
IGCDS_Fedplus1 & -0.129 & -1.294 & 0.015 & 0.137 & & & & \\
IGCDS_Fed & 0.267 & 1.924. & -0.063 & -0.403 & 0.464 & $2.864^{* *}$ & & \\
IGCDS_Fedminus1 & 0.153 & 0.990 & -0.187 & -1.118 & 0.246 & 1.308 & 0.031 & 0.231 \\
RSIplus2res & -1.466 & $-2.705^{* *}$ & & & & & & \\
RSIplus1res & 0.427 & 0.931 & -0.310 & -0.623 & & & & \\
RSIFedres & -1.069 & -1.734. & -1.038 & -1.698. & -0.253 & -0.362 & & \\
RSIminus1res & -0.015 & -0.045 & -0.564 & -1.494 & -0.563 & -1.464 & -0.331 & -1.223 \\
RVIplus2res & -0.225 & $-2.253^{*}$ & & & & & & \\
RVIplus1res & -0.023 & -0.243 & -0.112 & -1.109 & & & & \\
RVIFedres & -0.156 & -1.633 & -0.137 & -1.372 & -0.020 & -0.182 & & \\
RVIminus1res & -0.042 & -0.575 & -0.079 & -0.967 & -0.048 & -0.516 & -0.088 & -1.283 \\
\hline
\end{tabular}

$* * *, * *, *,$. , indicate significance at 0.001, and $0.01,0.5$ and 0.1 respectively. 
Session A and B of Table 6 summarize the cross impact between VIX and SPX. As we can see that there is no significant cross residual impact between VIX and SPX on FED day and one trading day later. This might imply the information is digested at the same time between SPX and VIX on those two days. Starting from two trading days after the FED announcement, we begin to see significant cross residual impact. For example, RSVplus1res is significant for VIX_Fedplus2 and at the same time both RVSplus1res and RVSminus1res are significant for SPX_Fedplus2. Same story for the third trading day after FED announcement: RSVplus1res is significant in explaining VIX_Fedplus3 and at the same time RVSplus1res is significant in explaining SPX_Fedplus3. Since the residuals of VIX and SPX are symmetric in explaining each other, it leads us to believe that SPX and VIX are more likely to move simultaneously after information shock rather than having a lead-lag movement relationship.

When we extend the analysis to include IGCDS, we see a similar result: VIX and SPX residuals are impacting each other in a symmetric way, which might imply that VIX and SPX are more likely to co-move with each other around exogenous information shock. The story with IGCDS is a little bit different. IGCDS residuals have no impact on VIX or SPX for all the trading days around FED Announcement; while SPX residual starts to have impact on IGCDS on the second trading day and then becomes extremely significant in explaining the third day movement of IGCDS (RSIplus2res is significant at $0.1 \%$ level). RVIplus2res is also significant in explaining the movement of IGCDS on day 3, but at a less significant level (RVIplus2res is significant at 5\% level). This suggests that on average, SPX and VIX tend to lead the movement of IGCDS, but the significant impact starts to show up only after two days of FED announcement.

We also classify days into negative FED days and positive FED days to study whether the information content makes a difference in terms of the market responses. The negative FED days are defined as the FED announcement day when the daily return of SPX is negative on that day while the positive FED days are the opposite. The results of the two-step regressions for negative FED days and positive FED days are presented in 7 and 8 respectively.

Table 7. Two-Step Regression Results for Negative FED Announcement Day

Table 7 shows the two-step regressions results for negative FED Announcement Day. Negative announcement day is defined as the FED announcement day when the daily return of SPX on that day is negative.

\begin{tabular}{|c|c|c|c|c|c|c|c|c|}
\hline \multicolumn{9}{|c|}{ A: Two-Step Regression of VIX on SPX Residual Impact only } \\
\hline & \multicolumn{2}{|c|}{ VIX_Fedplus3 } & \multicolumn{2}{|c|}{ VIX_Fedplus2 } & \multicolumn{2}{|c|}{ VIX_Fedplus1 } & \multicolumn{2}{|l|}{ VIX_Fed } \\
\hline & Estimate & t value & Estimate & $\mathrm{t}$ value & Estimate & $\mathrm{t}$ value & Estimate & $\mathrm{t}$ value \\
\hline (Intercept) & -0.006 & -1.591 & -0.004 & -1.269 & -0.003 & -0.525 & 0.010 & $2.554^{*}$ \\
\hline VIX_Fedplus2 & -0.273 & -1.586 & & & & & & \\
\hline VIX_Fedplus1 & -0.209 & -1.872 . & -0.067 & -0.667 & & & & \\
\hline VIX_Fed & 0.045 & 0.311 & -0.054 & -0.413 & 0.004 & 0.022 & & \\
\hline VIX_Fedminus1 & 0.081 & 0.509 & 0.086 & 0.664 & 0.142 & 0.734 & 0.033 & 0.217 \\
\hline RSVplus2res & -2.291 & -1.357 & & & & & & \\
\hline RSVplus1res & 2.339 & $2.719^{* *}$ & -2.143 & $-3.035 * *$ & & & & \\
\hline RSVFedres & -0.664 & -0.467 & 0.954 & 0.743 & 0.133 & 0.069 & & \\
\hline RSVminus1res & -0.651 & -1.135 & 0.084 & 0.160 & -0.831 & -1.130 & -0.075 & -0.133 \\
\hline \multicolumn{9}{|c|}{ B: Two-Step Regression of SPX on VIX Residual Impact only } \\
\hline & \multicolumn{2}{|c|}{ SPX_Fedplus3 } & \multicolumn{2}{|c|}{ SPX_Fedplus2 } & \multicolumn{2}{|c|}{ SPX_Fedplus1 } & \multicolumn{2}{|l|}{ SPX_Fed } \\
\hline & Estimate & t value & Estimate & $\mathrm{t}$ value & Estimate & $\mathrm{t}$ value & Estimate & $\mathrm{t}$ value \\
\hline (Intercept) & 0.002 & 1.908 & 0.000 & -0.401 & 0.001 & 0.673 & -0.004 & $-6.141 * * *$ \\
\hline SPX_Fedplus2 & -0.069 & -0.262 & & & & & & \\
\hline SPX_Fedplus1 & -0.712 & $-6.201 * * *$ & 0.067 & 1.009 & & & & \\
\hline SPX_Fed & 0.383 & 1.632 & -0.083 & -0.596 & 0.349 & 1.148 & & \\
\hline SPX_Fedminus1 & -0.013 & -0.115 & 0.080 & 1.217 & 0.307 & $2.144^{*}$ & -0.012 & -0.169 \\
\hline RVSplus2res & 0.055 & 0.811 & & & & & & \\
\hline RVSplus1res & -0.127 & $-2.439 *$ & 0.077 & $2.752 * *$ & & & & \\
\hline RVSFedres & -0.066 & -1.249 & -0.003 & -0.106 & -0.025 & -0.346 & & \\
\hline RVSminus1res & -0.038 & -0.777 & -0.057 & $-2.128^{*}$ & 0.059 & 0.985 & -0.031 & -1.082 \\
\hline
\end{tabular}




\begin{tabular}{|c|c|c|c|c|c|c|c|c|}
\hline \multicolumn{9}{|c|}{ C: Two-Step Regression of VIX on Residual Impact of SPX and IGCDS } \\
\hline & \multicolumn{2}{|c|}{ VIX_Fedplus3 } & \multicolumn{2}{|c|}{ VIX_Fedplus2 } & \multicolumn{2}{|c|}{ VIX_Fedplus1 } & \multicolumn{2}{|l|}{ VIX_Fed } \\
\hline & Estimate & $t$ value & Estimate & $t$ value & Estimate & $t$ value & Estimate & t value \\
\hline (Intercept) & 0.003 & 0.698 & -0.003 & -0.442 & 0.006 & 0.847 & 0.012 & $2.698^{*}$ \\
\hline VIX_Fedplus2 & -0.363 & $-2.752^{*}$ & & & & & & \\
\hline VIX_Fedplus 1 & -0.307 & $-3.081 * *$ & -0.023 & -0.137 & & & & \\
\hline VIX_Fed & -0.199 & -1.582 & -0.115 & -0.507 & 0.090 & 0.310 & & \\
\hline VIX_Fedminus1 & 0.108 & 0.813 & -0.019 & -0.095 & 0.258 & 1.077 & 0.096 & 0.630 \\
\hline RSVplus2res & -2.897 & -1.322 & & & & & & \\
\hline RSVplus1res & 2.837 & $3.662 * *$ & -2.285 & -1.874 & & & & \\
\hline RSVFedres & -3.190 & -1.893. & -0.359 & -0.119 & -1.952 & -0.543 & & \\
\hline RSVminus1res & -1.398 & $-2.861^{*}$ & 0.137 & 0.157 & -1.221 & -1.399 & -0.037 & -0.068 \\
\hline RIVplus2res & -1.086 & $-3.314 * *$ & & & & & & \\
\hline RIVplus1res & 0.208 & 0.813 & -0.018 & -0.039 & & & & \\
\hline RIVFedres & -0.109 & -0.233 & 0.307 & 0.400 & -0.040 & -0.042 & & \\
\hline RIVminus1res & -1.008 & $-2.771 *$ & -0.078 & -0.142 & 0.045 & 0.063 & 0.670 & 1.429 \\
\hline \multicolumn{9}{|c|}{ D: Two-Step Regression of SPX on Residual Impact of VIX and IGCDS } \\
\hline & \multicolumn{2}{|c|}{ SPX_Fedplus3 } & \multicolumn{2}{|c|}{ SPX_Fedplus2 } & \multicolumn{2}{|c|}{ SPX_Fedplus2 } & \multicolumn{2}{|l|}{ SPX_Fed } \\
\hline & Estimate & t value & Estimate & $\mathrm{t}$ value & Estimate & t value & Estimate & $\mathrm{t}$ value \\
\hline (Intercept) & 0.000 & -0.047 & 0.001 & 0.543 & -0.001 & -0.288 & -0.003 & $-5.528 * * *$ \\
\hline SPX_Fedplus2 & -0.062 & -0.187 & & & & & & \\
\hline SPX_Fedplus1 & -0.739 & $-5.492 * * *$ & 0.134 & 1.403 & & & & \\
\hline SPX_Fed & -0.033 & -0.116 & -0.041 & -0.176 & 0.644 & 1.331 & & \\
\hline SPX_Fedminus1 & 0.069 & 0.574 & 0.006 & 0.059 & 0.581 & $3.642 * *$ & 0.010 & 0.183 \\
\hline RVSplus2res & 0.097 & 1.289 & & & & & & \\
\hline RVSplus1res & -0.151 & $-3.549 * *$ & 0.056 & 1.819 . & & & & \\
\hline RVSFedres & 0.059 & 1.009 & 0.033 & 0.714 & 0.077 & 0.782 & & \\
\hline RVSminus1res & 0.010 & 0.238 & -0.036 & -1.331 & 0.034 & 0.592 & -0.015 & -0.623 \\
\hline RISplus2res & 0.290 & $3.135^{* *}$ & & & & & & \\
\hline RISplus1res & -0.037 & -0.518 & -0.019 & -0.332 & & & & \\
\hline RISFedres & 0.190 & 1.444 & -0.120 & -1.251 & 0.193 & 0.952 & & \\
\hline RISminus1res & 0.077 & 0.746 & 0.072 & 1.052 & 0.007 & 0.046 & -0.073 & -1.210 \\
\hline \multicolumn{9}{|c|}{ E: Two-Step Regression of IGCDS on the Residual Impact of SPX and VIX } \\
\hline & \multicolumn{2}{|c|}{ IGCDS_Fedplus3 } & \multicolumn{2}{|c|}{ IGCDS_Fedplus2 } & \multicolumn{2}{|c|}{ IGCDS_Fedplus1 } & \multicolumn{2}{|c|}{ IGCDS_Fed } \\
\hline & Estimate & t value & Estimate & t value & Estimate & t value & Estimate & $\mathrm{t}$ value \\
\hline (Intercept) & 0.004 & 1.715 & 0.000 & -0.041 & 0.003 & 1.061 & 0.004 & $2.664^{*}$ \\
\hline IGCDS_Fedplus2 & -0.140 & -0.574 & & & & & & \\
\hline IGCDS_Fedplus1 & -0.307 & -1.572 & 0.244 & 1.470 & & & & \\
\hline IGCDS_Fed & -0.347 & -1.139 & -0.029 & -0.113 & -0.115 & -0.344 & & \\
\hline IGCDS_Fedminus 1 & -0.020 & -0.069 & -0.605 & $-2.7^{*}$ & 0.017 & 0.057 & 0.165 & 1.011 \\
\hline RSIplus2res & -1.661 & -0.935 & & & & & & \\
\hline RSIplus1res & 0.128 & 0.204 & -1.159 & $-2.321 *$ & & & & \\
\hline RSIFedres & -1.256 & -0.920 & 0.618 & 0.498 & -1.816 & -1.220 & & \\
\hline RSIminus1res & -0.412 & -1.042 & -0.110 & -0.308 & -0.668 & -1.847 & -0.355 & -1.851. \\
\hline RVIplus2res & -0.209 & -0.971 & & & & & & \\
\hline RVIplus1res & -0.058 & -0.480 & -0.145 & -1.432 & & & & \\
\hline RVIFedres & -0.311 & -1.852 & 0.075 & 0.499 & -0.121 & -0.627 & & \\
\hline RVIminus1res & -0.019 & -0.153 & -0.119 & -1.340 & -0.073 & -0.644 & 0.034 & 0.517 \\
\hline
\end{tabular}

***, ${ }^{* *}, *,$. , indicate significance at 0.001 , and $0.01,0.5$ and 0.1 respectively. 
Table 8. Two-Step Regression Results for Positive FED Announcement Day

Table 8 displays the two-step regressions results for positive Fed Announcement Day only. Positive Announcement Day is defined as the FED Announcement Day when the daily return of SPX is positive.

\begin{tabular}{|c|c|c|c|c|c|c|c|c|}
\hline \multicolumn{9}{|c|}{ A: Two-Step Regression of VIX on SPX Residual Impact only } \\
\hline & \multicolumn{2}{|c|}{ VIX_Fedplus3 } & \multicolumn{2}{|c|}{ VIX_Fedplus2 } & \multicolumn{2}{|c|}{ VIX_Fedplus1 } & \multicolumn{2}{|l|}{ VIX_Fed } \\
\hline & Estimate & t value & Estimate & $\mathrm{t}$ value & Estimate & t value & Estimate & t value \\
\hline (Intercept) & 0.006 & 1.235 & 0.002 & 0.545 & -0.007 & -1.418 & -0.025 & $-9.202 * * *$ \\
\hline VIX_Fedplus2 & -0.046 & -0.346 & & & & & & \\
\hline VIX_Fedplus1 & -0.171 & -1.530 & -0.201 & -1.971. & & & & \\
\hline VIX_Fed & 0.096 & 0.645 & 0.007 & 0.054 & -0.344 & $-2.165^{*}$ & & \\
\hline VIX_Fedminus1 & -0.082 & -0.802 & -0.093 & -0.997 & 0.011 & 0.099 & -0.281 & $-3.72 * * *$ \\
\hline RSVplus2res & 0.593 & 0.711 & & & & & & \\
\hline RSVplus1res & 0.592 & 0.690 & 0.449 & 0.555 & & & & \\
\hline RSVFedres & 0.900 & 1.015 & 0.017 & 0.021 & 0.493 & 0.537 & & \\
\hline RSVminus1res & -0.557 & -0.637 & 0.313 & 0.383 & -1.192 & -1.243 & 0.955 & 1.352 \\
\hline \multicolumn{9}{|c|}{ B: Two- Step Regression of SPX on VIX Residual Impact only } \\
\hline & \multicolumn{2}{|c|}{ SPX_Fedplus3 } & \multicolumn{2}{|c|}{ SPX_Fedplus2 } & \multicolumn{2}{|c|}{ SPX_Fedplus1 } & \multicolumn{2}{|l|}{ SPX_Fed } \\
\hline & Estimate & t value & Estimate & $\mathrm{t}$ value & Estimate & $\mathrm{t}$ value & Estimate & t value \\
\hline (Intercept) & 0.000 & 0.104 & 0.000 & 0.018 & 0.000 & 0.229 & 0.005 & $9.366^{* * *}$ \\
\hline SPX_Fedplus2 & 0.021 & 0.146 & & & & & & \\
\hline SPX_Fedplus1 & -0.196 & -1.663 & -0.171 & -1.739 & & & & \\
\hline SPX_Fed & 0.071 & 0.451 & -0.130 & -0.969 & -0.262 & -1.609 & & \\
\hline SPX_Fedminus1 & 0.057 & 0.466 & -0.237 & $-2.337^{*}$ & 0.195 & 1.591 & -0.281 & $-3.452 * * *$ \\
\hline RVSplus2res & 0.044 & 1.107 & & & & & & \\
\hline RVSplus1res & 0.091 & $2.146^{*}$ & 0.031 & 0.858 & & & & \\
\hline RVSFedres & 0.062 & 1.415 & -0.084 & $-2.405^{*}$ & -0.001 & -0.019 & & \\
\hline RVSminus1res & 0.053 & 1.411 & 0.012 & 0.366 & 0.034 & 0.854 & -0.007 & -0.224 \\
\hline \multicolumn{9}{|c|}{ C: Two-Step Regression of VIX on Residual Impact of SPX and IGCDS } \\
\hline & \multicolumn{2}{|c|}{ VIX_Fedplus3 } & \multicolumn{2}{|c|}{ VIX_Fedplus2 } & \multicolumn{2}{|c|}{ VIX_Fedplus1 } & \multicolumn{2}{|l|}{ VIX_Fed } \\
\hline & Estimate & t value & Estimate & $\mathrm{t}$ value & Estimate & t value & Estimate & t value \\
\hline (Intercept) & 0.015 & $2.36^{*}$ & 0.013 & 1.843. & -0.010 & -1.248 & -0.026 & $-5.962 * * *$ \\
\hline VIX_Fedplus2 & -0.295 & -1.882 & & & & & & \\
\hline VIX_Fedplus 1 & 0.014 & 0.114 & -0.144 & -1.071 & & & & \\
\hline VIX_Fed & 0.356 & 2. & 0.148 & 0.699 & -0.432 & $-2.037^{*}$ & & \\
\hline VIX_Fedminus1 & -0.227 & -1.661 & -0.109 & -0.818 & 0.012 & 0.079 & -0.322 & $-3.226 * *$ \\
\hline RSVplus2res & 1.762 & 1.363 & & & & & & \\
\hline RSVplus1res & -0.193 & -0.127 & -1.409 & -0.801 & & & & \\
\hline RSVFedres & 1.327 & 0.777 & -1.554 & -0.965 & 0.578 & 0.342 & & \\
\hline RSVminus1res & 3.031 & 1.828 & 3.350 & $2.114^{*}$ & -2.985 & -1.537 & 1.258 & 0.905 \\
\hline RIVplus2res & 0.801 & $3.057 * *$ & & & & & & \\
\hline RIVplus1res & -0.452 & -1.596 & -0.367 & -1.120 & & & & \\
\hline RIVFedres & 0.684 & 1.379 & -0.014 & -0.026 & 0.234 & 0.365 & & \\
\hline RIVminus1res & 0.625 & 1.351 & 0.583 & 1.103 & -0.163 & -0.261 & -0.309 & -0.663 \\
\hline
\end{tabular}




\section{D: Two-Step Regression of SPX on Residual Impact of VIX and IGCDS}

\begin{tabular}{|c|c|c|c|c|c|c|c|c|}
\hline & \multicolumn{2}{|c|}{ SPX_Fedplus3 } & \multicolumn{2}{|c|}{ SPX_Fedplus2 } & \multicolumn{2}{|c|}{ SPX_Fedplus2 } & \multicolumn{2}{|l|}{ SPX_Fed } \\
\hline & Estimate & $t$ value & Estimate & $\mathrm{t}$ value & Estimate & $\mathrm{t}$ value & Estimate & $\mathrm{t}$ value \\
\hline (Intercept) & 0.000 & -0.258 & -0.001 & -0.822 & 0.001 & 0.805 & 0.005 & $5.928 * * *$ \\
\hline SPX_Fedplus2 & -0.215 & -0.940 & & & & & & \\
\hline SPX_Fedplus1 & 0.064 & 0.368 & -0.238 & -1.686 & & & & \\
\hline SPX_Fed & 0.366 & 1.491 & -0.168 & -0.895 & -0.422 & $-2.115^{*}$ & & \\
\hline SPX_Fedminus1 & -0.170 & -0.759 & -0.501 & $-3.367 * *$ & 0.237 & 1.267 & -0.305 & $-2.467 *$ \\
\hline RVSplus2res & 0.105 & 2.024 & & & & & & \\
\hline RVSplus1res & 0.151 & 2.180 & 0.023 & 0.389 & & & & \\
\hline RVSFedres & 0.065 & 1.161 & -0.065 & -1.499 & 0.012 & 0.249 & & \\
\hline RVSminus1res & 0.086 & 1.365 & -0.037 & -0.700 & 0.020 & 0.301 & -0.012 & -0.238 \\
\hline RISplus2res & -0.277 & $-4.381 * * *$ & & & & & & \\
\hline RISplus1res & 0.074 & 1.083 & 0.062 & 1.082 & & & & \\
\hline RISFedres & -0.007 & -0.056 & -0.130 & -1.359 & -0.147 & -1.247 & & \\
\hline RISminus1res & -0.277 & -2.483 & -0.115 & -1.249 & 0.109 & 0.950 & -0.027 & -0.304 \\
\hline \multicolumn{9}{|c|}{ E: Two-Step Regression of IGCDS on the Residual Impact of SPX and VIX } \\
\hline & \multicolumn{2}{|c|}{ IGCDS_Fedplus3 } & \multicolumn{2}{|c|}{ IGCDS_Fedplus2 } & \multicolumn{2}{|c|}{ IGCDS_Fedplus1 } & \multicolumn{2}{|c|}{ IGCDS_Fed } \\
\hline & Estimate & t value & Estimate & $\mathrm{t}$ value & Estimate & t value & Estimate & t value \\
\hline (Intercept) & -0.004 & -1.289 & -0.001 & -0.180 & 0.001 & 0.204 & -0.009 & $-4.567 * * *$ \\
\hline IGCDS_Fedplus2 & 0.563 & $4.351 * * *$ & & & & & & \\
\hline IGCDS_Fedplus1 & -0.154 & -1.209 & -0.070 & -0.434 & & & & \\
\hline IGCDS_Fed & 0.266 & 1.250 & -0.019 & -0.066 & 0.615 & $2.511^{*}$ & & \\
\hline IGCDS_Fedminus1 & 0.119 & 0.570 & -0.014 & -0.051 & 0.404 & 1.485 & 0.068 & 0.442 \\
\hline RSIplus2res & 0.009 & 0.012 & & & & & & \\
\hline RSIplus1res & 0.132 & 0.147 & 0.689 & 0.572 & & & & \\
\hline RSIFedres & 0.593 & 0.585 & -0.899 & -0.815 & 0.068 & 0.070 & & \\
\hline RSIminus1res & 1.756 & 1.784 & -1.131 & -1.042 & -1.900 & -1.705 & -0.367 & -0.546 \\
\hline RVIplus2res & -0.160 & -1.255 & & & & & & \\
\hline RVIplus1res & -0.047 & -0.276 & 0.015 & 0.063 & & & & \\
\hline RVIFedres & 0.055 & 0.401 & -0.084 & -0.493 & 0.074 & 0.472 & & \\
\hline RVIminus1res & 0.007 & 0.044 & -0.118 & -0.569 & -0.247 & -1.203 & -0.142 & -1.086 \\
\hline
\end{tabular}

$* * *, * *, *,$. , indicate significance at 0.001 , and $0.01,0.5$ and 0.1 respectively.

We start from the negative FED day results. Between only SPX and VIX, the story is similar with the overall results. The residuals of SPX and VIX are symmetric in explaining each other, suggesting that most likely; the two variables were moving at the same time with information shock. Stories are slightly different when IGCDS is introduced into system. First, same as before, we see that SPX residuals are significant in explaining IGCDS movements. For example, RSIplus1res is significant in explain ICGDS_Fedplus2 and RSIminue1res is significant in explaining both IGCDS_Fed and IGCDS_Fedplus1. This suggests that SPX is more likely to have a leading movement than IGCDS on the Fed day as well as two trading days after. However, different from previous results, on the third trading day after negative FED announcement, IGCDS residuals are significant in explaining both the movements of SPX and VIX (both RIVplus2res and RISplus2res are significant in the regression) and on the other hand, all the SPX residuals are not significant in explaining IGCDS_Fedplus3. This is consistent with whole sample analysis that SPX tends to lead IGCDS around Fed announcement until two trading days after the information shock. However, it seems that the negative information content tend to take longer for IGCDS to digest (the impact last longer until the $3^{\text {rd }}$ day after FED Announcement). 
The case with positive FED day is a different story. First, between VIX and SPX only, we see that SPX residuals have no impact on the VIX movement, while some of the VIX residuals are significant in explaining SPX. For example, RVSFedres is significant in SPX_Fedplus2 regression and RVSfedplus1res is significant in explaining SPX_Fedplus3. This suggests that with positive information shock, VIX tends to have a slightly leading impact on SPX, starting two trading days after the news. When we add ICGDS into the system, we see that consistent with negative FED day results, IGCDS plus2 residuals are very significant in explaining both SPX and VIX. At the same time, the VIX residuals have no explanatory power for IGCDS regressions, while SPXminus1res is significant in explaining both IGCDS_Fedplus1 and IGCDS_Fedplus3. This is kind of consistent with our previous results that SPX tends to lead IGCDS around FED Announcement after the information shock. On the other hand, IGCDS responds to the information shock with a longer residual impact on both SPX and VIX, until three days later.

\section{Conclusions}

It has long been a debate about whether financial markets are efficient enough to reflect information immediately and completely. The efficient-market hypothesis $(\mathrm{EMH})$ asserts that financial markets are "information efficient", i.e. all relevant information will be fully and immediately reflected in a security's market price, and thus investors should not expect to earn an abnormal return (above the market return) through either technical analysis or fundamental analysis. Other researchers however, have disputed the efficient-market hypothesis both empirically and theoretically.

In this paper, we investigate the research question whether investment information will be reflected in different security markets simultaneously. In another words, we empirically test the lead-lag correlations among various financial indices. If efficient market hypothesis is held true, we should expect to see a simultaneous co-movement among various security markets; while on the other hand, if different security markets digest and reflect information with different speeds, then we should expect to see some lead-lag relationship.

We focus on three major financial markets: stock market, derivative markets and fixed-income markets and we investigate the movement of major financial indices which are proxies of these security markets. We perform two types of analysis: (1) a VAR analysis on daily data to investigate the general lead-lag relationship among various security markets; (2) we introduce exogenous information shock (FED announcement) and investigate the responses from various financial markets.

Our results indicate that VIX and SPX tend to co-move with each other while they have a circular lead-lag relationship with Index PCR.ratio and IGCDS. On the flip side, although IGCDS seems to respond to the information with a certain lag but it has a longer residual impact (three trading days after event) on both VIX and SPX.

Our overall findings suggest that all three major financial markets (equity, fixed income and derivative) are closely correlated; however, we do see certain level of lead-lag relationships among the movements of our variables.

Our results will contribute to the literature in three perspectives:

(1) Our analysis provides certain evidence that is against the efficient market hypothesis

(2) Our results also offer insights towards a better understanding about the speed of different security markets processing and reflecting information.

(3) It will also benefit investors who wish to profit from arbitraging among different security markets by taking advantage of the different speeds that information is processed and reflected in different security markets.

\section{References}

Aizenman, Joshua, Binici Mahir \& Michael Hutchison. (2014). The Transmission of Federal Reserve Tapering News to Emerging Financial Markets, working paper, http://escholarship.org/uc/item/7n17z9km

Ball, Ray J. \& P. Brown. (1968). An empirical evaluation of accounting income numbers', Journal of Accounting Research, Autumn, pp. 159-178. http://dx.doi.org/10.2307/2490232

Bernanke, B. S., \& K. N. Kuttner. (2005). What Explains the Stock Market's Reaction to Federal Reserve Policy?," The Journal of Finance, 60(3), 1221-1257. http://dx.doi.org/10.1111/j.1540-6261.2005.00760.x

Bernard, V. \& J. Thomas. (1989). Post-earnings-announcement drift: Delayed price response or risk premium? Journal of Accounting Research, Suppl. 27, pp.1-36.

Bernard, V. \& J. Thomas. (1990). Evidence that Stock Prices Do Not Fully Reflect the Implications of Current Earnings for Future Earnings, Journal of Accounting and Economics, 13, pp.305-340. http://dx.doi.org/10.1016/0165-4101(90)90008-R

Berndt, Antje \& Anastasiya Ostrovnaya. (2007). Information Flow between Credit Default Swap, Option and Equity Markets, working paper.

Birru, Justin \& Stephen Figlewski. (2010). The Impact of the Federal Reserve's Interest Rate Target Announcement on Stock Prices: A Closer Look at How the Market Impounds New Information, NYU working paper. http://pages.stern.nyu.edu/ sfiglews/Docs/Fed\%20Announcements_OCT212010.pdf 
Brooks, Chris, Alistair G. Rew \& Stuart Ritson. (2001). A trading strategy based on the lead-lag relationship between the spot index and futures contract for the FTSE 100, International Journal of Forecasting, Volume 11, issue 1, pp.31-44. http://dx.doi.org/10.1016/S0169-2070(00)00062-5

Case, Bradford, Yawei Yang, \& YildirayYildirim. (2012). Dynamic correlations among asset classes: REIT and stock returns, The Journal of Real Estate Finance and Economics. 44.3, pp.298-318. http://dx.doi.org/10.1007/s11146-010-9239-2

Conover, C. Mitchell \& David R. Peterson. (1999). The Lead-Lag Relationship Between the Option and Stock Markets Prior to Substantial Earnings Surprises and the Effect of Securities Regulation, Journal of Financial and Strategic Decisions, 12.1., pp.41-52.

Corzo, M. Teresa, Gomez-Biscarri, Javier \& Lazcano, Laura. (2012). The Co-Movement of Sovereign Credit Default Swaps and Bonds, and Stock Markets in Europe.

De Jong, Frank \& Theo Nijman. (1997). High frequency analysis of lead-lag relationships between financial markets, Journal of Empirical Finance, Volume 4, issue 2-3, pp.259-277. http://dx.doi.org/10.1016/S0927-5398(97)00009-1

Downing, Chris, Underwood, Shane \& Xing, Yuhang. (2009). The Relative Information Efficiency of Stocks and Bonds: An Intraday Analysis, Journal of Financial and Quantitative Analysis, Volume 44, Issue 5, pp 1081-1102. http://dx.doi.org/10.1017/S0022109009990305

Fonseca, Jose De \& Katrin, Gottschalk. (2012). The Co-movement of Credit Default Swap Spreads, Stock Market Returns and Volatilities: Evidence from Asia-Pacific Markets, working paper.

Goto, Shingo, \&Valkanov, Rossen. (2000). The Fed's Effect on Excess Returns and Inflation is Much Bigger Than You Think. Manuscript, UCLA Anderson School.

Herbst, Anthony, Joseph R. McCormack \& Elizabeth N. West. (1987). Investigation of a lead-lag relationship between spot stock indices and their futures contracts, Journal of Futures Markets, Volume 7, Issue 4, pp. 373-381. http://dx.doi.org/10.1002/fut.3990070403

Hong, Harrison, Torous, Walter \& Rossen Volkanov. (2007). Do Industries Lead Stock Maret, Journal of Financial Economics, Volume 83, issue 2, pp. 367-396. http://dx.doi.org/10.1016/j.jfineco.2005.09.010

Ilter, H. Kemal \& Alguner, Ayhan. (2013). Lead Lag Relationship and Price Discovery in Turkish Stock Exchange and Futures Markets, African Journal of Business Management, Volume 7, issue 41, pp.4254-4262.

Izani, I \& Che, Raflis. O. (2004). the Lead-Lag Pattern of Leading, Coincident and Lagging Indicators in Malaysia, Investment Management and Financial Innovations, 2004/2, pp 34-41.

Jusoh, Hashim, Bacha, Obiyathulla \& Masih, Abul Mansur M. (2014). Multi-scale Lead-Lag Relationship between the Stock and Futures Markets: Malaysia as a Case Study, working paper. Online at http://mpra.ub.uni-muenchen.de/56954/, MPRA Paper No. 56954, posted 29. June 2014 05:41 UTC

Kolluri, Bharat, Susan Machuga \& Mahmoud Wahab. (2014). Co-Movements of US and Asian Equity Markets: Evidence from Asymmetric and Time-Varying Coefficients, Review of Pacific Basin Financial Markets and Policies Volume 17, Issue 4, pp 1450021-1— 44.

Mishra, Prachi, Kenji Moriyama, Papa N'Diaye, \& Lam Nguyen. (2014). Impact of Fed Tapering Announcements on Emerging Markets, IMF working paper, https://www.imf.org/external/pubs/ft/wp/2014/wp14109.pdf

Norden, Lars \& Weber, Martin. (2009). The Comovement of Credit Default Swap, Bond and Stock Markets: an Empirical Analysis, European Financial Management, Volume 15, Issue 3, pp. 529-562. http://dx.doi.org/10.1111/j.1468-036X.2007.00427.x

Refet S Gürkaynak, Brian Sack \& Eric Swanson. (2005). Do Actions Speak Louder Than Words? The Response of Asset Prices to Monetary Policy Actions and Statements, International Journal of Central Banking, vol. 1(1), pp 55-93.

Sathya Swaroop Debasish. (2009). An econometric analysis of the lead-lag relationship between India's NSE Nifty and its derivative contracts, The Journal of Risk Finance, Vol. 10 Iss: 4, pp.350 - 364. http://dx.doi.org/10.1108/15265940910980650

Tse, Y.K. (1995). Lead-lag relationship between spot index and futures price of the nikkei stock average, Journal of Forecasting, Volume 14, Issue 7, pp. 553-563. http://dx.doi.org/10.1002/for.3980140702

\section{Notes}

Note 1. The CBOE S\&P 500 PutWrite Index (ticker symbol PUT) is a benchmarking index that measures the performance of a hypothetical portfolio that sells S\&P 500 Index (SPX) put options against collateralized cash reserves held in a money market account. 
Appendix 1 List of Variables and Descriptions in the Two-Step Regression Analysis

\begin{tabular}{|c|c|}
\hline Data Variable & Description \\
\hline VIX_Fedminus1 & The daily change of VIX on one trading day before Fed Announcement \\
\hline VIX_Fed & The daily change of VIX on the day of Fed Announcement \\
\hline VIX_Fexplus1 & The daily change of VIX on the first trading day after Fed Announcement \\
\hline VIX_Fedplus2 & The daily change of VIX on the second trading day after Fed Announcement \\
\hline VIX_Fedplus3 & The daily change of VIX on the third trading day after Fed Announcement \\
\hline SPX_Fedminus1 & The daily change of SPX on one trading day before Fed Announcement \\
\hline SPX_Fed & The daily change of SPX on the day of Fed Announcement \\
\hline SPX_Fedplus1 & The daily change of SPX on the first trading day after Fed Announcement \\
\hline SPX_Fedplus2 & The daily change of SPX on the second trading day after Fed Announcement \\
\hline SPX_Fedplus3 & The daily change of SPX on the third trading day after Fed Announcement \\
\hline IGCDS_Fedminus1 & The daily change of IGCDS on one trading day before Fed Announcement \\
\hline IGCDS_Fed & The daily change of IGCDS on the day of Fed Announcement \\
\hline IGCDS_Fedplus1 & The daily change of IGCDS on the first trading day after Fed Announcement \\
\hline IGCDS_Fedplus2 & The daily change of IGCDS on the second trading day after Fed Announcement \\
\hline IGCDS_Fedplus3 & The daily change of IGCDS on the third trading day after Fed Announcement \\
\hline RVSminus1res & The residual from the regression of VIX_Fedminus1 on SPX_Fedminus1 \\
\hline RVSFedres & The residual from the regression of VIX_Fed on SPX_Fed ${ }^{-}$ \\
\hline RVSplus1res & The residual from the regression of VIX_Fedplus1 on SPX_Fedplus1 \\
\hline RVSplus2res & The residual from the regression of VIX_Fedplus2 on SPX_Fedplus2 \\
\hline RVSplus3res & The residual from the regression of VIX_Fedpus3 on SPX_Fedplus3 \\
\hline RSVminus1res & The residual from the regression of SPX_Fedminus1 on VIX_Fedminus1 \\
\hline RSVFedres & The residual from the regression of SPX_Fed on VIX_Fed \\
\hline RSVplus1res & The residual from the regression of SPX_Fedplus1 on VIX_Fedplus1 \\
\hline RSVplus2res & The residual from the regression of SPX_Fedplus2 on VIX_Fedplus2 \\
\hline RSVplus3res & The residual from the regression of SPX_Fedpus3 on VIX_Fedplus3 \\
\hline RVIminus1res & The residual from the regression of VIX_Fedminus1 on IGCDS_Fedminus1 \\
\hline RVIFedres & The residual from the regression of VIX_Fed on IGCDS_Fed \\
\hline RVIplus1res & The residual from the regression of VIX_Fedplus1 on IGCDS_Fedplus1 \\
\hline RVIplus2res & The residual from the regression of VIX_Fedplus2 on IGCDS_Fedplus2 \\
\hline RVIplus3res & The residual from the regression of VIX_Fedpus3 on IGCDS_Fedplus3 \\
\hline RSIminus1res & The residual from the regression of SPX_Fedminus1 on IGCDS_Fedminus1 \\
\hline RSIFedres & The residual from the regression of SPX_Fed on IGCDS_Fed \\
\hline RSIplus1res & The residual from the regression of SPX_Fedplus1 on IGCDS_Fedplus1 \\
\hline RSIplus2res & The residual from the regression of SPX_Fedplus2 on IGCDS_Fedplus2 \\
\hline RSIplus3res & The residual from the regression of SPX_Fedpus3 on IGCDS_Fedplus3 \\
\hline RIVminus1res & The residual from the regression of IGCDS_Fedminus1 on VIX_Fedminus1 \\
\hline RIVFedres & The residual from the regression of IGCDS_Fed on VIX_Fed \\
\hline RIVplus1res & The residual from the regression of IGCDS_Fedplus1 on VIX_Fedplus1 \\
\hline RIVplus2res & The residual from the regression of IGCDS_Fedplus2 on VIX_Fedplus2 \\
\hline RIVplus3res & The residual from the regression of IGCDS_Fedpus3 on VIX_Fedplus3 \\
\hline RISminus1res & The residual from the regression of IGCDS_Fedminus1 on SPX_Fedminus1 \\
\hline RISFedres & The residual from the regression of IGCDS_Fed on SPX_Fed ${ }^{-}$ \\
\hline RISplus1res & The residual from the regression of IGCDS_Fedplus1 on SPX_Fedplus1 \\
\hline RISplus2res & The residual from the regression of IGCDS_Fedplus2 on SPX_Fedplus2 \\
\hline RISplus3res & The residual from the regression of IGCDS_Fedpus3 on SPX_Fedplus3 \\
\hline
\end{tabular}

